19 Revue d'histoire du XIXe siècle

Société d'histoire de la révolution de 1848 et des

révolutions du XIXe siècle

$6 \mid 1990$

Le XIXe siècle en question

\title{
Le XIXe siècle en question [transcription de table ronde]
}

Jean-Claude Caron

(2) OpenEdition

Journals

Electronic version

URL: http://journals.openedition.org/rh19/45

DOI: $10.4000 /$ rh 19.45

ISSN: $1777-5329$

Publisher

La Société de 1848

Printed version

Date of publication: 1 June 1990

ISSN: 1265-1354

Electronic reference

Jean-Claude Caron, «Le XIXe siècle en question [transcription de table ronde] », Revue d'histoire du XIXe siècle [Online], 6 | 1990, Online since 09 September 2008, connection on 19 April 2019. URL : http://journals.openedition.org/rh19/45 ; DOI : 10.4000/rh19.45

This text was automatically generated on 19 April 2019

Tous droits réservés 


\section{Le XIXe siècle en question [transcription de table ronde]}

Jean-Claude Caron

\section{ABSTRACTS}

No abstract available by now

Pas de résumé disponible actuellement

INDEX

Mots-clés: Débat 